E-ISSN : 2549-6581

DOI: 10.21776/ub.JOIM.2019.003.03.3

Artikel Hasil Penelitian

Diterima : 29 Mei 2019

Direview : 16 Oktober 2019

Dimuat : Desember 2019 - Maret 2020
OPEN ACCESS

Journal of Issues in Midwifer

\title{
PENGARUH PEMBERIAN VITAMIN C DAN VITAMIN E TERHADAP LAMA SIKLUS ESTRUS TIKUS (Rattus norvegicus) GALUR WISTAR BETINA YANG DIBERI RHODAMIN B
}

\author{
Maulida Diah Setiawati ${ }^{\left.1^{*}\right)}$, Lilik Indahwati ${ }^{2}$, Husnul Khotimah ${ }^{3}$ \\ ${ }^{1 *}$ Program Studi S1 Kebidanan, Fakultas Kedokteran, Universitas Brawijaya, \\ E-mail: maulidadiah@gmail.com; TIp: +6281357656351 \\ ${ }^{2}$ Program Studi S1 Kebidanan, Fakultas Kedokteran, Universitas Brawijaya, \\ E-mail: lulikw.ub@gmail.com \\ ${ }^{3}$ Program Studi Magister Ilmu Biomedik, Fakultas Kedokteran, Universitas Brawijaya, Email: \\ husnul farmako.fk@ub.ac.id
}

\begin{abstract}
Rhodamin $B$ is a food coloring that is still widely used and has an impact on reproductive hormone balance disorders that can affect the estrous cycle in mice. This study goal is to know the effect of vitamin $C$, vitamin $E$, and combination of both vitamin to estrous cycle rats given rhodamin $B$. Twenty five female rats divided into five random groups, negative control group (without treatment); positif control group given rhodamin B; rhodamin B group and vitamin $C$ (600 $\mathrm{mg} / \mathrm{kgBW}) ;$ rhodamin $B$ group and vitamin $E(40 \mathrm{IU} / \mathrm{kgBW})$, rhodamin $B$ group which given both vitamin. Rhodamin $B$ was given orally. Estrous cycle were observed from characteristic of every phase on estrous cycle. The result of this study was analysed used one way anova. Vitamin $C$ and combination of both vitamin can shorter the estrous cycle $(P<0,05)$, but vitamin E can't shorter the estrous cycle $(P>0,05)$.
\end{abstract}

Key words: Rhodamin B, vitamin C, vitamin E, estrous cycle

\begin{abstract}
ABSTRAK
Rhodamin B adalah pewarna makanan yang masih banyak digunakan dan memiliki dampak terhadap gangguan keseimbangan hormon reproduksi yang dapat mempengaruhi lama siklus estrus pada tikus. Penelitian dilakukan untuk membuktikan pengaruh vitamin $\mathrm{C}$, vitamin $\mathrm{E}$, maupun kombinasi keduanya terhadap lama siklus estrus tikus (Rattus norvegicus) yang telah diberi rhodamin B. Dua puluh lima tikus betina dewasa dikelompokkan kedalam lima kelompok acak, Kelompok negative (tanpa perlakuan); Kelompok positif (diberi Rhodamin B $90 \mathrm{mg} / \mathrm{kgBB} / \mathrm{hari}$ ), kelompok rhodamin B yang diberi vitamin $\mathrm{C}(600 \mathrm{mg} / \mathrm{kgBB} /$ hari), kelompok rhodamin $B$ yang diberi vitamin $E$ (40 IU/ $/ \mathrm{kgBB} /$ hari), kelompok rhodamin $B$ yang diberi vitamin $E$ dan vitamin $\mathrm{C}$. Fase dalam siklus estrus diamati dengan mengamati ciri-ciri vaginal swab. Analisis data menggunakan ANOVA. Hasil dalam penelitian ini membuktikan bahwa vitamin $\mathrm{C}$ serta kombinasi kedua vitamin dapat memperlambat panjang siklus
\end{abstract}


estrus $(p<0,05)$, sedangkan vitamin $E$ tidak dapat memperlambat siklus estrus $(p>$ $0,05)$.

Kata Kunci: Rhodamin B, vitamin $C$, vitamin $E$, siklus estrus

*Korespondensi: Cindy Irmayanti. Surel: cindyirmayanti1@gmail.com

\section{PENDAHULUAN}

Rhodamin B (Rh B) sebagai zat aditif merupakan pewarna makanan yang berbahaya namun masih banyak digunakan. ${ }^{1,2}$ Rhodamin B dapat mengganggu hormon reproduksi yang dapat mengganggu siklus estrus dengan memperpanjang siklus, sehingga siklus menjadi tidak normal. Terganggunya siklus estrus merupakan salah satu tanda ketidaksuburan pada sistem reproduksi. ${ }^{3}$

Rhodamin B merupakan zat xenobiotik yang dapat menghasilkan radikal bebas (ROS) dan merupakan salah satu penyebab terjadinya infertilitas pada wanita. ${ }^{4}$ ROS memiliki elektron yang tidak berpasangan, mampu mengoksidasi molekul disekitarnya, memicu stress oksidatif menyebabkan terjadi ketidakseimbangan antara radikal bebas dan antioksidan yang dapat memicu apoptosis sel di ovarium tikus dan mengganggu keseimbangan hormon. 5,6,7

Antioksidan dapat mengikat atau memberikan 1 elektron kepada radikal bebas. Antioksidan yang dapat melawan efek tersebut adalah vitamin $\mathrm{E}$ dan vitamin C. Vitamin C atau ascorbic acid dapat melawan efek dari radikal bebas, polusi, senyawa toksik dan merupakan antioksidan utama yang larut dalam air, plasma, dan jaringan. Vitamin C dapat mendukung daur ulang redoks a-tokoferol. ${ }^{8,9}$

Vitamin E sebagai antioksidan telah terbukti dapat mempengaruhi ketebalan endometrium dan mengobati wanita dengan masalah infertilitas. ${ }^{10}$ Kombinasi dua vitamin tersebut juga menimbulkan sistem pertahanan melalui pemutusan reaksi radikal. ${ }^{9}$

Penggunaan rhodamin $B$ dalam jangka panjang dapat menyebabkan stress oksidatif, sehingga dapat mengganggu kinerja hormon pada sistem reproduksi seperti FSH, LH, progesteron, dan estrogen yang dapat memperpanjang lama siklus estrus. ${ }^{3}$ Bedasarkan hal tersebut maka perlu dilakukan penelitian mengenai pengaruh pemberian vitamin $C$ dan vitamin $E$ sebagai antioksidan terhadap siklus estrus pada tikus yang telah dipapar rhodamin B.

\section{METODE}

\section{Hewan Coba}

Dua puluh lima tikus, dengan berat 150-250 g dikelompokkan menjadi 5 kelompok acak, pengelompokan bedasarkan dengan rumus Frederer 
yaitu kelompok K- tanpa perlakuan, kelompok $\mathrm{K}+$ hanya diberi rhodamin $B$ dengan dosis $90 \mathrm{mg} / \mathrm{KgBB} / \mathrm{hari}$, kelompok $\mathrm{P} 1$ diberi rhodamin $\mathrm{B}$ dan vitamin C $600 \mathrm{mg} / \mathrm{KgBB} / \mathrm{hari}$, kelompok P2 diberi rhodamin $\mathrm{B}$ dan vitamin E $40 \mathrm{lU} / \mathrm{KgBB} /$ hari, P3 diberi rhodamin $B$ dan kombinasi vitamin $C$ dan vitamin E. Rhodamin B, vitamin $C$ dan Vitamin E diberikan selama 15 hari hingga $3 x$ siklus setelah 15 hari pemberian.

\section{Rhodamin B}

Rhodamin B Sigma Aldrich C.I 45170 dilarutkan dalam $1 \mathrm{ml}$ aquabides diberikan secara peroral.

\section{Vitamin C}

Vitamin $C$ dengan merk dagang CIPI dilarutkan dengan aquabides 1 $\mathrm{ml}$.

\section{Vitamin E}

Vitamin $E$ dengan merk dagang Nature-E dilarutkan dengan minyak jagung $1 \mathrm{ml}$.

\section{Swab Vagina}

Swab vagina dilakukan sebelum diberikan perlakuan selama 2 kali siklus, serta selama 3 kali siklus pada hari ke 15 setelah diberi perlakuan. Parameter yang diamati adalah bentuk sel epitel setiap fase. Pengambilan sampel sitologi dilakukan 1 kali sehari pada pukul 07.00-08.00. Pembuatan preparat apusan vagina dilakukan dengan cara mengambil cairan vagina pada lokasi kira-kira $1-2 \mathrm{~cm}$ dari vulva menggunakan cotton bud yang dibasahi dengan $\mathrm{NaCl}$ fisiologis $0,9 \%$. Hasil usapan dioleskan pada gelas objek dan preparat difiksasi dengan alkohol $70 \%$ dibiarkan sampai kering, setelah kering dilakukan pewarnaan Giemsa 3\%. Pengamatan dilakukan menggunakan mikroskop cahaya dengan pembesaran lensa objektif $40 x$.

\section{Etik}

Keterangan kelaikan etik No.348/EC/KEPK-S1-KB/12/2018

\section{Analisis Statistik}

Data disajikan dengan delta rata-rata pretest posttest lama siklus estrus $\pm S D$, perbedaan antar kelompok dianalisis menggunakan ANOVA dan antar dua kelompok menggunakan post hoc dengan SPSS 21.0.

\section{HASIL}

Lama siklus estrus dapat
diamati dengan membedakan
karakteristik tiap fase.



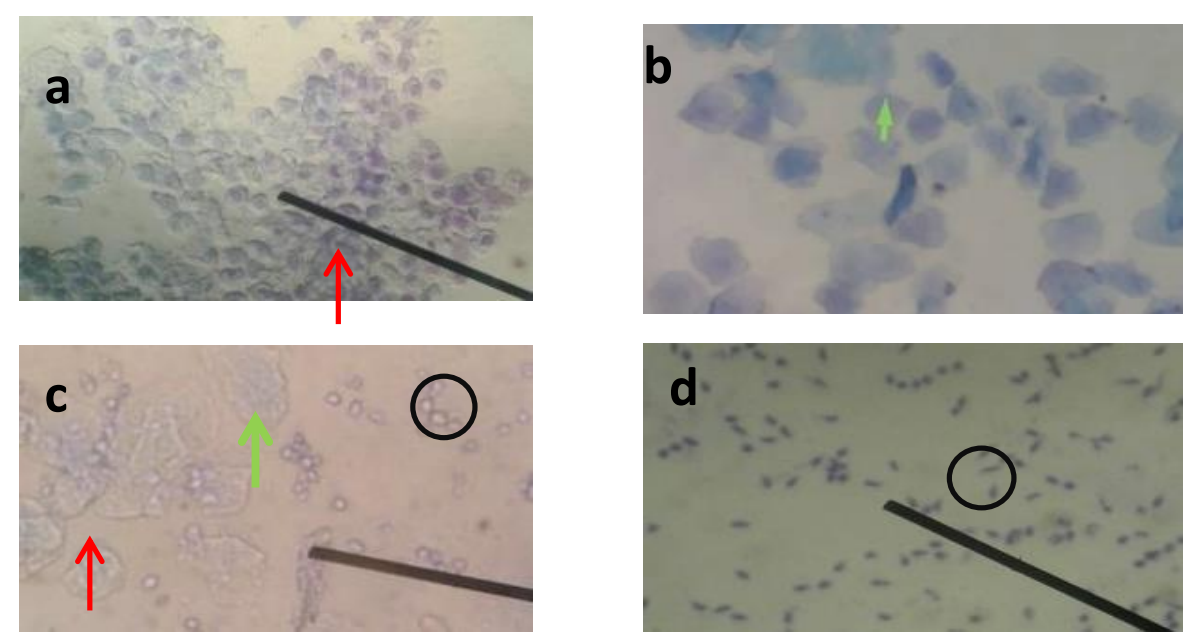

Gambar 1. Siklus Estrus Tikus. (a) Fase Proestrus, (b) Fase Estrus, (c) Fase Metestrus, (d) Fase Diestrus. Panah merah menunjukkan sel epitel berinti. Panah hijau menunjukkan sel epitel terkornifikasi, dan lingkaran menunjukkan leukosit.

Hasil perhitungan dianalasis, menunjukkan delta pretest-posttest rata-rata lama siklus estrus antar kelompok terdapat perbedaan yang bermakna secara statistik yaitu $p=$ 0.036 . Selanjutnya dilakukan uji post hoc LSD untuk mengetahui perbedaan antara dua kelompok perlakuan (Tabel 1).

\section{PEMBAHASAN}

Bedasarkan hasil uji post hoc (Tabel 1) menunjukkan perbedaan yang bermakna rerata delta lama siklus estrus $\mathrm{K}$ - dan $\mathrm{K}+$. Hal ini membuktikan bahwa kelompok tikus yang diberi rhodamin $B$ memiliki siklus yang lebih panjang apabila dibandingkan dengan kelompok tikus yang sehat.

Salah satu tanda kesuburan pada wanita adalah siklus reproduksi yang teratur.
Siklus menstruasi yang teratur, menandakan adanya maturasi oosit dan pengeluaran hormon yang teratur. ${ }^{11}$

Siklus estrus merupakan siklus reproduksi pada tikus rattus norvegicus, siklus ini menggambarkan siklus menstruasi pada wanita. Siklus estrus normalnya berlangsung selama 4-5 hari, memiliki 4 fase dimana setiap fase memiliki karakteristik yang berbeda dan dipengaruhi oleh perubahan hormon yang berubah secara fisiologis. 12 Rhodamin B merupakan salah satu zat xenobiotik yang dapat meningkatkan ROS berupa hidroksil radikal $(\cdot \mathrm{OH})$ dan singlet oksigen ${ }_{1} \mathrm{O}^{2}$ dapat mengaktivasi sitokrom P450 memproduksi ROS yaitu hidroksil peroksida $\left(\mathrm{H}_{2} \mathrm{O}_{2}\right)$ dan anion superoksida $\left(\mathrm{O}_{2}{ }^{-}\right) .{ }^{9,13,14}$ Rhodamin $\mathrm{B}$ dapat memicu kondisi stress 
Tabel 1 Rerata delta pretest posttest lama siklus estrus

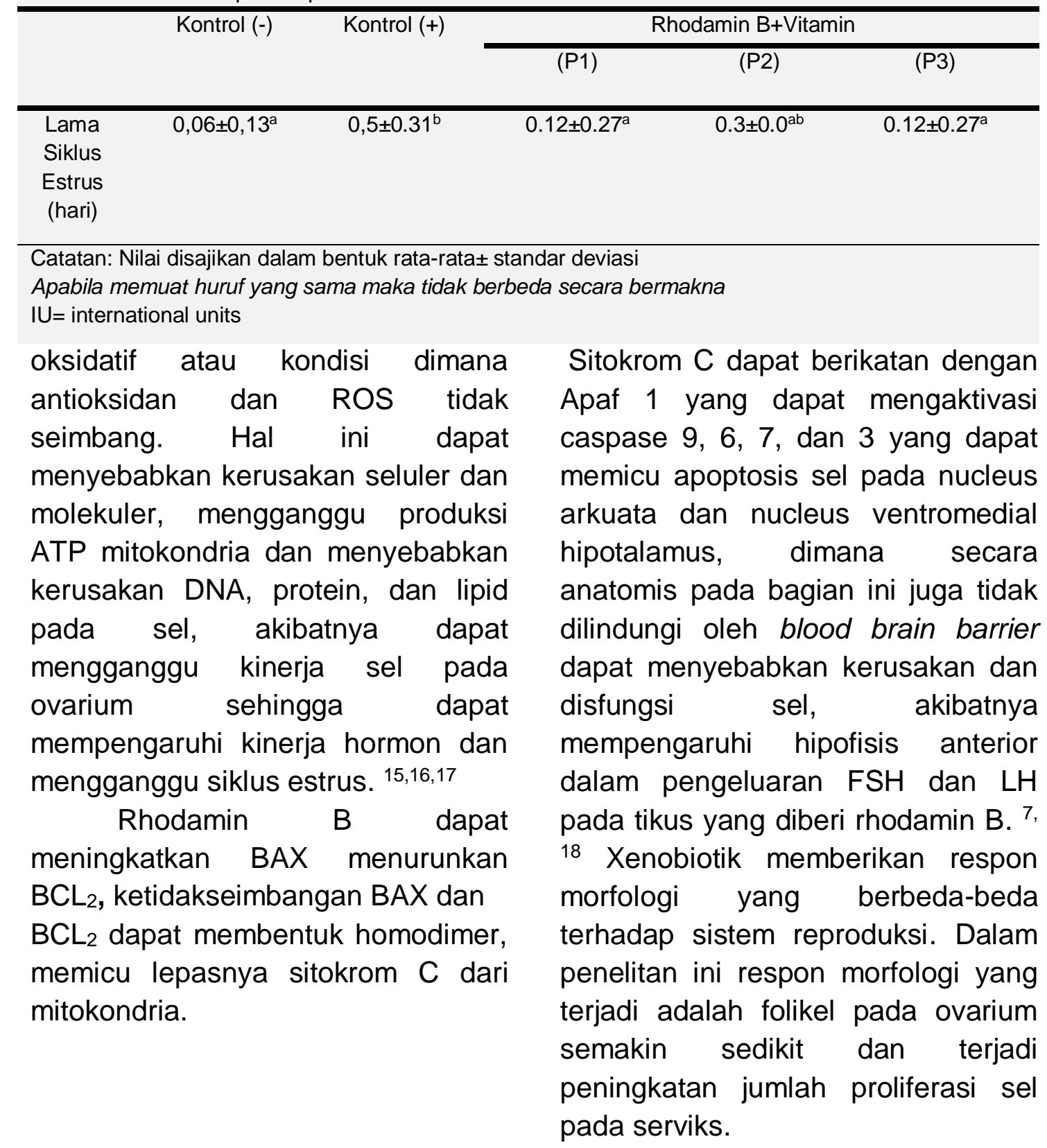


Hal ini dapat terjadi karena FSH dan LH menurun meningkatkan sintesis hormon reproduksi yaitu esterogen. Penurunan hormon FSH dan LH memicu atropi ovarium karena terjadi penurunan jumlah folikel, dan kondisi ini dapat memicu folikular cysts dimana folikel pada ovarium gagal untuk ovulasi.

Namun, kondisi ini dapat memicu peningkatan sirkulasi hormon esterogen, progesteron, atau kombinasi keduanya yang dapat mengakibatkan hiperplasia dan hipertropi pada uterus dan vagina, dominansi esterogen tersebut diikuti hiperplasia sel squamous vagina sehingga menyebabkan kondisi seperti estrus. ${ }^{15}$

Kelompok P1 secara signifikan memiliki siklus yang lebih singkat apabila dibandingkan dengan kelompok $\mathrm{K}+$. Vitamin $\mathrm{C}$ (ascorbic acid) dapat memicu disfungsi organ dengan cara mereduksi radikal bebas seperti singlet oksigen $10^{2}$, anion superoksida $\mathrm{O}_{2}^{-}, \quad$ hidrogen peroksida $\left(\mathrm{H}_{2} \mathrm{O}_{2}\right)$, dan peroxynitrite serta dapat mencegah terjadinya peroksidasi lipid.8,19 Vitamin C memiliki 1 molekul askorbat anion $\left(\right.$ Asc $\left.\mathrm{H}^{-}\right)$yang merupakan donor antioksidan utama bereaksi dengan radikal bebas. ${ }^{20}$ Beberapa penelitian juga menunjukkan bahwa vitamin C dapat meningkatkan kadar progesterone pada wanita infertil, menurunkan kadar MDA pada testis, meningkatkan FSH dan $\mathrm{LH} .{ }^{21}$

Kelompok P2 memiliki siklus lebih singkat apabila dibandingkan dengan kelompok $\mathrm{K}_{+}$namun perbedaan ini tidak berbeda secara bermakna. Vitamin E adalah vitamin yang larut lemak, bekerja dalam membran sel, dan dapat mereduksi $\mathrm{O}_{2}{ }^{-}, \mathrm{H}_{2} \mathrm{O}_{2}$, dan $\mathrm{OH}$ dengan memutus rantai ikatan radikal selama proses peroksidasi lipid. ${ }^{24,25}$ Beberapa penelitian juga meunjukkan bahwa vitamin $\mathrm{E}$ kurang efektif dalam menurunkan hiperglikemia pada reproduksi pria, apabila dibanding dengan vitamin $C$, maupun gabungan kedua vitamin, vitamin C lebih protektif dibanding vitamin E. 22,23

Terjadi perbedaan yang bermakna antara P3 dengan $\mathrm{K}+$, namun apabila dilihat dari grafik yang ada, hasil P3 menunjukkan nilai yang sama dengan $\mathrm{P} 1$. Vitamin $C$ dapat mereduksi radikal bebas secara langsung serta dapat meregenerasi $\alpha$-tocopherol radikal menjadi $\alpha$-tocopherol kembali apabila mendonasikan hidrogennya. ${ }^{20}$ Kombinasi vitamin C dan vitamin E dapat bekerjasama dengan baik untuk mengatasi efek dari radikal bebas dengan target organ yang berbeda.

\section{SIMPULAN}

$\begin{array}{lllr}\text { Rhodamin } & \text { B } & \text { dapat } \\ \text { memperpanjang } & \text { lama } & \text { siklus } \\ \text { estrus. Vitamin } & \text { C, kombinasi }\end{array}$


vitamin C dan vitamin E dapat memperpendek siklus estrus tikus yang telah diberi rhodamin $B$. Vitamin E sendiri tidak dapat memperpendek siklus estrus tikus yang telah diberi rhodamin $\mathrm{B}$.

\section{DAFTAR PUSTAKA}

1. Shen J., Wu Y., Zhang B., Li F.. Adsorption of Rhodamine B Dye by Biomimetic Mesoperus SiO2. Nanosheets. Technology Enviromental Policy 2014; 17: 2289-2298

2. Kemenkes. Permenkes RI Nomor 239/Men.kes/Per/V/85 tentang zat warna tertentu yang dinyatakan sebagai bahan berbahaya. 1985.

3. Febrina G. R., Wiratmini N. I., \& Sudatri N. W.. Pengaruh Pemberian Rhodamin B terhadap Siklus Estrus Mencit (Mus Musculus L.) Betina. Jurnal Biologi Udayana. 2013; 17(1).

4. Purnamawati, Y., Suyasa B, Mahardika. Penurunan Kadar Rhodamin B dalam Air Limbah dengan Biofiltrasi Sistem Tanaman. Ecotrophic. 2015; 9 (02).

5. Wedhasari A. Peran Antioksidan bagi Kesehatan. Jurnal Biotek Medisiana Indonesia. 2014; 3(2): 59-68

6. Laili A.N., Ananingsih I., Wiyasa IWA., dkk. Protective Effect of Combined Vitamin $\mathrm{C}$ and $\mathrm{E}$ against Ovarian and Endometrial Toxicity in Rats that Receiving Oral Rhodamine B. Biomarkers and
Genomic Medicine. 2015; (7) 154158

7. Sulistina D.R., Ratnawati R., Wiyasa I.W.A.. Rhodamine B Increase Hypothalamic Cell Apoptosis and Disrupts Hormonal Balance in Rats. Asian Pasific Journal of reproduction . 2014; 3 (3): 180-183

8. Combs G. F., and McClung J. P.. Vitamin C. In The Vitamins 2017a; 267-295

9. Yuslianti E.R. Pengantar Radikal Bebas dan Antioksidan. Yogyakarta: Deepublish. 2018.

10. Cicek N., Eryilmaz O.G., Sarikaya E. et al.. Vitamin E Effect on Controlled Ovarian Stimulation of Unexplined Infertile Women. J Assist Reprod Genet. 2012; 29: 325.

11. Woldemeskel M. Toxicologic Pathology of the Reproductive System. Reprodutive and Developmental Toxicology. 2004.

12. Life Science Weekly. Estrous Cycle. Color Response. 2013.

13. Mohamed MA., Nair A., Sandhya.. Role of Reactive Species in the Visible Light Photocatalytic Mineralization of Rhodamin B Dye by P25- Carbon dot Photocatalyst. Dyes and Pigments. 2018.

14. Rezende F., Prior KK., Löwe O., Wittig I., Strecker V., Moll F et al.. Cytochrome P450 Enzymes But Not NADPH Oxidases Are The Source of the NADPH-dependent Lucigenin Chemiluminescence in Membrane Assays. Free Radical 
Biology and Medicine. 2017; 102: 57-66.

15. Agarwal A., Mellado A., Premkumar B., Shaman A., Gupta S.. The Effects of Oxidative Stress on Female Reproduction: a Review. Reproductive Biology and Endocrinology. 2012; (10) 49.

16. Maqbool F., Mostafalou S., Bahadar H., Abdolahi M.. Review of Endocrine Disorders Associated with Enviromental Toxicants and Possible Involved Mechanisms. Life Sciences. 2015.

17. Roth Z. Reduction in Oocyte Developmental Competence by Stress is Associated with Alterations in Mitochondrial Function. American Dairy Science Association. 2018; 101:1-13.

18. Mohajeri M.,jimenez MC., Barreto G., Sahebkar A.. Effects of Estrogens and Androgens on Mitochondria Under Normal and Phathological Conditions. Progress in Neurobiology. 2018.

19. Singh P., Kesharwani R., Keservani R.. Antioxidants and Vitamins: Roles in Cellular Function and Metabolism. Sustained Energy for Enhanced Human Functions and Activity . 2017.

20. Trabe M., Stevans J.. Vitamins C and $E$ : Beneficial Effects from $A$ Mechanistic Perspective. Free Radic Biol Med. 2011; 51 (5): 1000-1013.

21. Mahdi H., tahereh H., Esmaiel S., Massood E.. Vitamins E and C Prevent Apoptosis of Testicular and Ovarian Tissues Following Mancozeb Exposure in the FirstGeneration Mouse Pups. Toxicologix and Industrial Health. 2019.

22. Combs GF., and McClung JP. Vitamin E. The Vitamins. 2017.

Tahan G., Aytac E., Aytekin H., Gunduz F., Dogusoy G., Aydin,S., et al. Vitamin E Has A Dual Effect Of Anti-Inflammatory and Antioxidant Activities in Acetic Acid-Induced Ulcerative Colitis In Rats. Canadian Journal of Surgery. 2011; 54(5): 333-338. 